Jurnal Riset Agama

Volume 1, Nomor 2 (Agustus 2021): 375-388

DOI: $10.15575 /$ jra.v1i2.14672

https://journal.uinsgd.ac.id/index.php/jra

\title{
Susu Sapi sebagai Obat bagi Kesehatan Tubuh: Studi Takhrij dan Syarah Hadits
}

\author{
Hilma Noor Salwa Zakiyyah \\ Jurusan Ilmu Al-Qur'an dan Tafsir, Fakultas Ushuluddin \\ UIN Sunan Gunung Djati Bandung, Indonesia \\ hilmansalwazakiyyah@gmail.com
}

\begin{abstract}
This study aims to discuss cow's milk as a medicine for body health. This study uses a qualitative type of method that emphasizes literature study through the takhrij and syarah hadith methods with contemporary analysis. The results of this study can be concluded that the quality status of the hadith about cow's milk as a medicine for body health is assessed by hasan li ghairihi based on the takhrij hadith. And the hadith syarah shows that cow's milk is a medicine for the health of the body which in cow's milk contains many nutrients so that it is beneficial for the health of the body. The conclusion of this study is that the hadith about cow's milk as a medicine for body health can be referred to as an Islamic practice because it has hasan li ghairihi status.
\end{abstract}

Keywords: Body; Cow; Health; Milk.

\begin{abstract}
Abstrak
Penelitian ini bertujuan untuk membahas tentang susu sapi sebagai obat bagi kesehatan tubuh. Penelitian ini menggunakan metode jenis kualitatif yang ditekankan pada studi pustaka melalui metode takhrij dan syarah hadis dengan analisis kontemporer. Hasil penelitian ini dapat disimpulkan bahwa status kualitas hadis tentang susu sapi sebagai obat bagi kesehatan tubuh dinilai hasan li ghairihi berdasarkan takhrij hadis. Dan syarah hadis menunjukkan bahwa susu sapi sebagai obat bagi kesehatan tubuh yang mana di dalam susu sapi terkandung banyak gizi sehingga bermanfaat untuk kesehatan tubuh. Kesimpulan penelitian ini ialah hadis tentang susu sapi sebagai oabat bagi kesehatan tubuh bisa dirujuk sebagai amalan Islam karena memiliki status hasan li ghairihi.
\end{abstract}

Kata kunci: Kesehatan; Sapi; Susu; Tubuh. 
Jurnal Riset Agama, Volume 1, Nomor 2 (Agustus 2021): 375-388

Hilma Noor Salwa Zakiyyah/Susu Sapi sebagai Obat bagi Kesehatan Tubuh:

Studi Takhrij dan Syarah Hadits

\section{Pendahuluan}

Susu adalah cairan berwarna putih, yang diperoleh dari perasan hewan yang menyusui, yang dapat dimakan atau digunakan sebagai bahan pangan yang sehat, serta padanya tidak dikurangi atau ditambahtambahi bahan lainnya. Susu merupakan protein nabati, yang mempunyai kandungan asam amino esensial yang lengkap (Hadiwiyoto 1994). Pada zaman Rasulullah Saw, air susu sudah dikenal mempunyai kandungan gizi yang sangat baik. Secara umum susu hewan yang dijumpai manusia dalam kehidupan sehari-hari, hanya diketahui sedikit manfaatnya, akan tetapi sesungguhnya susu hewan mempunyai manfaat yang banyak dilihat dari segi kesehatan. Susu yang menjadi kebutuhan manusia sejak kecil bisa menyegarkan dan bisa menjadi obat. Oleh karena itu wajar bila Nabi Muhammad Saw menyuruh umatnya untuk meminum susu. Dalam suatu peristiwa Nabi pernah ditawari oleh malaikat, minuman alcohol (miras) atau susu, ternyata Beliau memilih susu (Saltanera 2015). Nabi menyebutkan bahwa susu adalah minuman yang paling menyehatkan. Karena itu susu mendapat predikat makanan sempurna yang menyempurnakan menu. Di dalamnya terkandung semua zat yang diperlukan manusia sejak kecil. Susu sapi merupakan salah satu susu yang memiliki sumber protein hewani yang banyak banyak sekali manfaatnya, dan sebagai bahan pangan yang kaya akan kandungan berbagai zat gizi. Zat gizi yang terdapat dalam susu sapi membuat susu memiliki banyak khasiat bagi tubuh, antara lain untuk pertumbuhan, pemeliharaan, kesehatan, dan kecerdasan (Achroni 2013). Sapi diternakkan untu dikonsumsi daging dan susunya, meski cukup banyak juga yang dimanfaatkan untuk hal lain, seperti menarik kereta, gerobak, dan bajak. Sapi juga banyak disebutkan dalam Al-Qur'an, baik sebagai perumpamaan, petunjuk, maupun sebagai hewan dalam bentuk denotatif. Selain banyak disebutkan dalam Al-Qur'an, sapi juga banyak disebutkan dalam hadits.

Beberapa pakar sudah melakukan penelitian sebagaimana telah ditinjau dalam pustaka ini, seperti Wardyningrum (2011), “Tingkat Kognisi tentang Konsumsi Susu pada Ibu Peternak Sapi Perah Lembang Jawa Barat," Universitas Al-Azhar Indonesia. Penelitian ini membahas tentang pengetahuan ibu peternak sapi perah terhadap manfaat dan kandungan susu, meskipun hanya sebatas pengetahuan yang bersifat umum dan tidak diiringi dengan kebiasaan mengkonsumsi susu. Pengetahuan tentang karakteristik susu sangat memadai, pengetahuan yang cenderung rendah ialah tentang kandungan jenis susu selain susu sapi segar, pengetahuan tentang cara mengkonsumsi susu yang optimal, dan pengetahuan dalam mengolah susu sebagai alternative makanan atau 
Jurnal Riset Agama, Volume 1, Nomor 2 (Agustus 2021): 375-388

Hilma Noor Salwa Zakiyyah/Susu Sapi sebagai Obat bagi Kesehatan Tubuh:

Studi Takhrij dan Syarah Hadits

minuman. Pada penelitian ini metode yang digunakan adalah kuantitatif deskriptif dengan melakukan pengumpulan data (Wardyaningrum 2011). Machrus (2017), "Susu Hewan Ternak dalam Al-Qur'an (Kajian Tematik)," Universitas Islam Negeri Walisongo Semarang. Penelitian ini membahas penafsiran ayat-ayat Al-Qur'an tentang susu hewan. Dalam pandangan sains, susu pada awalnya berupa makanan yang dimakan oleh hewan rumansia (sapi, kambing, domba, unta) untuk menjadi susu melalu mekanisme biokimia yang rumit. Dalam penelitian ini menyebutkan bahwa susu memiliki kandungan zat yang sangat banyak seperti protein, vitamin, lemak dan mineral. Penelitian ini berjenis kualitatif yang merupakan penelitian kepustakaan dengan melakukan pengumpulan data pustaka (Machrus 2017). Christi (2019), "Pentingnya Minum Susu untuk Anak Usia Dini, Remaja dan Lanjut Usia di Pesisir Pangandaran," Universitas Padjajaran Sumedang. Penelitian ini membahas penyuluhan tentang pentingnya minum susu bagi anak usia dini, remaja, dan lanjut usia yang baik bagi kesehatan melalui metode SGD (Small Group Discusson). Materi penyuluhan melalui tahapan di antaranya pentingnya minum susu sebagai pengantar peranan serta manfaat susu dan diakhiri dengan praktik minum susu bersama. Pada penelitian ini metode yang digunakan adalah kuantitatif deskriptif dengan melakukan pengumpulan data (Christi, Raden Febrianto; Edianingsih, Primiani; Alhuur 2019).

Penelitian sebelumnya mengenai susu sapi yang telah diuraikan pada tinjauan pustaka sangat berkontribusi terhadap penyusunan kerangka berpikir ini. Susu merupakan bahan pangan yang sangat penting dalam kehidupan manusia. Hal ini sudah diketahui oleh orangorang yang hidup jauh sebelum Islam lahir, bahwasanya susu dapat mendorong pertumbuhan manusia dengan baik sejak bayi sampai dewasa (Hadiwiyoto 1994). Menurut Kamus Besar Bahasa Indonesia, susu merupakan air yang keluar dari buah dada, susu binatang, atau bahan minuman yang berupa. Sedangkan secara istilah, susu adalah cairan berwarna putih yang diperoleh dari manusia, pemerahan sapi atau hewan menyusui yang dapat diminum atau digunakan sebagai bahan yang sehat serta tidak dikurangi komponen-komponennya atau ditambah bahanbahan lain (Hadiwiyoto 1994). Zat gizi yang terdapat dalam susu sapi membuat susu memiliki banyak khasiat bagi tubuh, antara lain untuk pertumbuhan, pemeliharaan kesehatan, dan kecerdasan (Achroni 2013). Dengan berkembangnya pengetahuan, pemanfaatan susu sapi semakin meningkat. Bahkan sejak zaman dahulu, zaman para Nabi, susu dari hasil ternak sudah dimanfaatkan sebagai minuman yang menyehatkan dan juga air susu sudah dikenal mempunyai kandungan gizi yang sangat banyak. Secara istilah hadits ialah apa saja yang disandarkan kepada Nabi Muhammad Saw baik berupa perkataan, perbuatan, persetujuan atau sifat (Darmalaksana, Pahala, and Soetari 2017). Takhrij merupakan 
Jurnal Riset Agama, Volume 1, Nomor 2 (Agustus 2021): 375-388

Hilma Noor Salwa Zakiyyah/Susu Sapi sebagai Obat bagi Kesehatan Tubuh:

Studi Takhrij dan Syarah Hadits

penelusuran atas lokasi hadits dalam sumber-sumbernya yang asli yang menyebutkan hadits beserta sanadnya, untuk kemudian dikaji kualitas haditsnya (Darmalaksana 2020d; Soetari 2015). Definisi syarah hadits yang mencakup semua komponen baik sanad maupun matannya ialah menjelaskan keshahihan dan kecacatan sanad dan matan hadits, menjelaskan makna-maknanya, dan mengeluarkan hukum dan hikmahnya (Darmalaksana 2020e, 2020c; Taufik 2020).

Berdasarkan pada pemaparan tersebut, formula penelitian disusun seperti rumusan masalah penelitian, petanyaan utama penelitian, dan tujuan penelitian (Darmalaksana 2020a). Rumusan masalah terhadap penelitian ini ialah terdapat syarah hadits tentang susu sapi sebagai obat bagi kesehatan tubuh. Pertanyaan utama penelitian ini ialah bagaimana syarah hadits tentang susu sapi sebagai obat bagi kesehatan tubuh. Sedangkan pertanyaan penelitian secara terperinci yakni bagaimana teks hadits tentang susu sapi, bagaimana kualitas hadits tentang susu sapi. Tujuan penelitian ini yaitu membahas syarah hadits tentang susu sapi. Penelitian ini diharapkan bermanfaat bagi masyarakat yang ingin mengetahui tentang susu sapi sebagai obat bagi kesehatan tubuh.

\section{Metode Penelitian}

Penelitian ini menggunakan jenis kualitatif melalui studi pustaka (Darmalaksana 2020b). Pada menelitian ini metode yang digunakan adalah dengan menerapkan metode takhrij dan syarah (Darmalaksana 2020d; Soetari 2015) terhadap hadits yang berkenaan dengan susu sapi melalui analisis kontemporer (Darmalaksana 2020c; Masrur 2012; Nasrulloh 2020).

\section{Hasil dan Pembahasan}

Hasil penelitian dan pembahasan disajikan dalam beberapa hal.

\section{Teks Hadits Susu Sapi}

Berdasarkan pencarian hadits tentang susu sapi melalui aplikasi Ensiklopedia Hadits Kitab 9 Imam (Saltanera 2015), yang akan menjadi pembahasan utama dalam penelitian ini adalah hadis riwayat Ahmad No. 18077 Kitab Musnad Penduduk Kufah Bab Hadits Thariq bin Syihab radhiallahuta'ala'anhu, sebagai berikut.

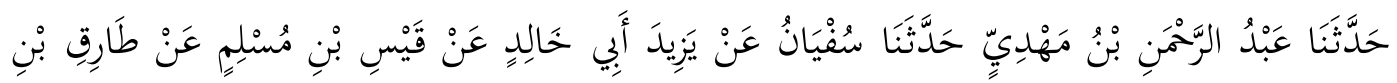

$$
\begin{aligned}
& \text { شِهَابِ }
\end{aligned}
$$

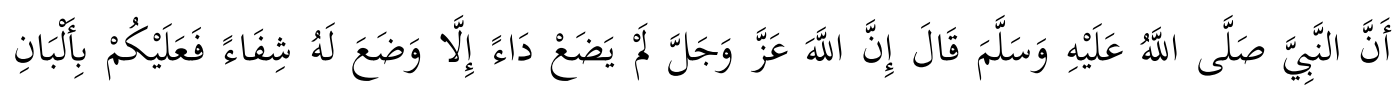

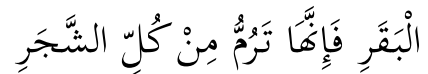


Jurnal Riset Agama, Volume 1, Nomor 2 (Agustus 2021): 375-388

Hilma Noor Salwa Zakiyyah/Susu Sapi sebagai Obat bagi Kesehatan Tubuh:

Studi Takhrij dan Syarah Hadits

Artinya: Telah menceritakan kepada kami Abdurrahman bin Mahdi Telah menceritakan kepada kami Sufyan dari Yazid bin Abu Khalid dari Qais bin Muslim dari Thariq bin Syihab bahwa Nabi bersabda, "Sesungguhnya Allah 'Azza wa Jalla belum pernah menurunkan penyakit, kecuali juga menurunkan obatnya. Karena itu, hendaklah kalian meminum susu Sapi, sebab ia makan dari beragam jenis dedaunan" (HR. Ahmad).

\section{Takhrij Hadis tentang Susu Sapi} berikut:

Takhrij hadis terkait susu sapi ditampilkan dalam bentuk tabel

\section{Tabel 1. Daftar Rawi Sanad}

\begin{tabular}{|c|c|c|c|c|c|c|c|c|}
\hline \multirow{3}{*}{ No. } & & \multirow{2}{*}{\multicolumn{2}{|c|}{$\begin{array}{l}\text { Lahir/ } \\
\text { Wafat }\end{array}$}} & \multirow{3}{*}{ Negeri } & \multicolumn{4}{|c|}{ Komentar } \\
\hline & \multirow{2}{*}{$\begin{array}{l}\text { Rawi } \\
\text { Sanad }\end{array}$} & & & & \multirow{2}{*}{ Kuniyah } & \multicolumn{2}{|c|}{ Ulama } & \multirow[t]{2}{*}{ Kalangan } \\
\hline & & $\mathrm{L}$ & W & & & - & + & \\
\hline 1 & $\begin{array}{l}\text { Thariq bin } \\
\text { Syihab bin } \\
\text { 'Abdu } \\
\text { Syams bin } \\
\text { Hilal bin } \\
\text { Salamah bin } \\
\text { 'Auf }\end{array}$ & & $\begin{array}{l}82 \\
\mathrm{H}\end{array}$ & Kufah & $\begin{array}{l}\text { Abu } \\
\text { ‘Abdullah }\end{array}$ & & $\begin{array}{l}\text { Ibnu Hajar } \\
\text { al- } \\
\text { Atsqalani: } \\
\text { Shahabat }\end{array}$ & Shahabat \\
\hline
\end{tabular}


Jurnal Riset Agama, Volume 1, Nomor 2 (Agustus 2021): 375-388

Hilma Noor Salwa Zakiyyah/Susu Sapi sebagai Obat bagi Kesehatan Tubuh: Studi Takhrij dan Syarah Hadits

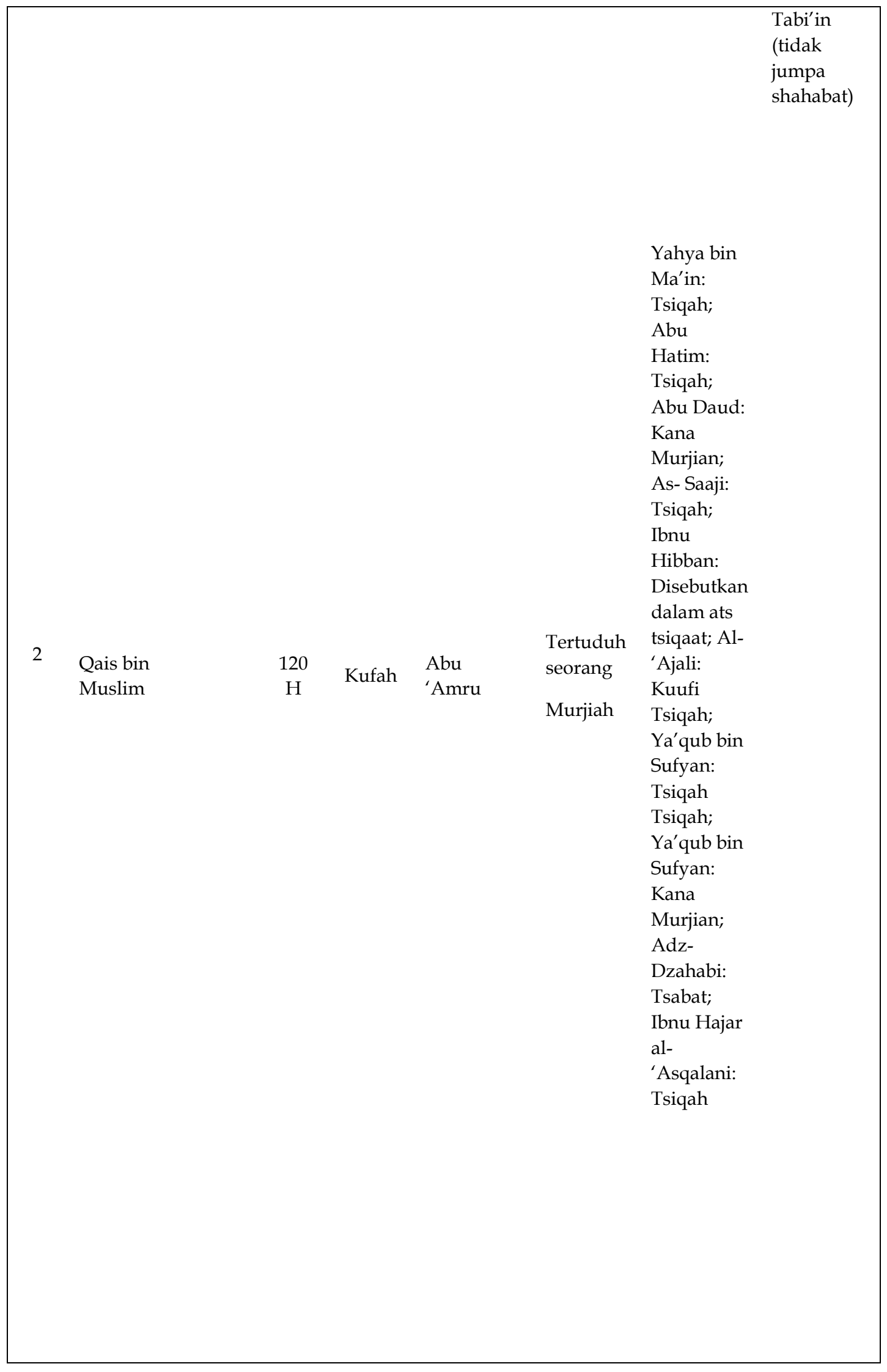


Jurnal Riset Agama, Volume 1, Nomor 2 (Agustus 2021): 375-388

Hilma Noor Salwa Zakiyyah/Susu Sapi sebagai Obat bagi Kesehatan Tubuh: Studi Takhrij dan Syarah Hadits

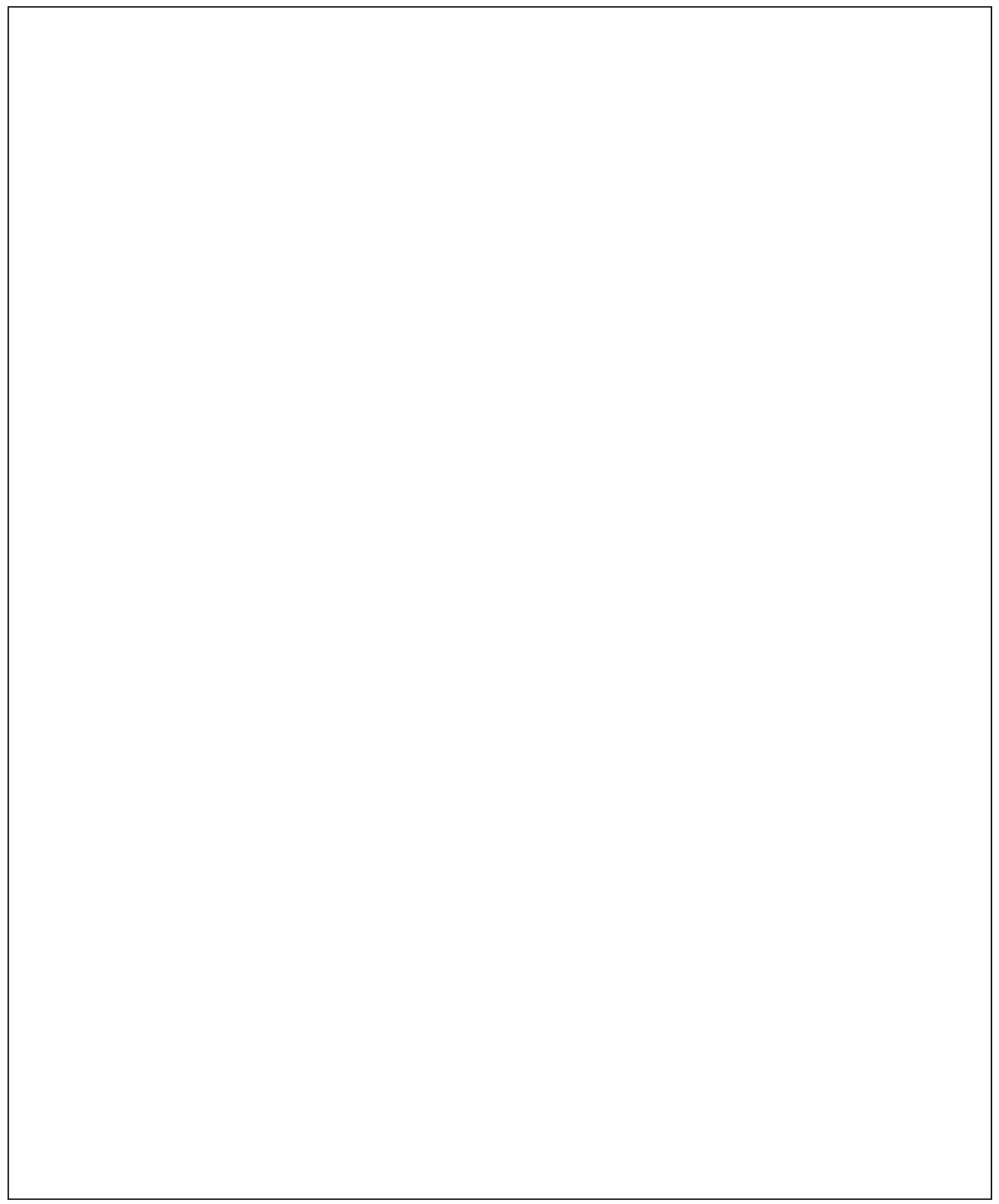


Jurnal Riset Agama, Volume 1, Nomor 2 (Agustus 2021): 375-388

Hilma Noor Salwa Zakiyyah/Susu Sapi sebagai Obat bagi Kesehatan Tubuh:

Studi Takhrij dan Syarah Hadits

\begin{tabular}{|c|c|c|c|c|c|c|}
\hline 3 & $\begin{array}{l}\text { Yazid bin } \\
\text { 'Abdur } \\
\text { Rahman }\end{array}$ & & Kufah & $\begin{array}{l}\text { Abu } \\
\text { Khalid }\end{array}$ & $\begin{array}{l}\text { Ahmad bin } \\
\text { Hambal: } \\
\text { La ba'sa } \\
\text { bih; Yahya } \\
\text { bin Ma'in: } \\
\text { Laisa bihi } \\
\text { ba's; Abu } \\
\text { Hatim: } \\
\text { Shaduuq } \\
\text { tsiqah; An- } \\
\text { Nasa'i: } \\
\text { Laisa bihi } \\
\text { ba's; Ibnu } \\
\text { Sa'd: } \\
\text { Mungkarul } \\
\text { hadits }\end{array}$ & $\begin{array}{l}\text { Tabi'ut } \\
\text { Tabi'in } \\
\text { kalangan } \\
\text { tua }\end{array}$ \\
\hline 4 & $\begin{array}{l}\text { Sufyan bin } \\
\text { Sa'id bin } \\
\text { Masruq }\end{array}$ & $\begin{array}{c}161 \\
\mathrm{H}\end{array}$ & Kufah & $\begin{array}{l}\text { Abu } \\
\text { 'Abdullah }\end{array}$ & $\begin{array}{l}\text { Malik bin } \\
\text { anas: } \\
\text { Tsiqahh; } \\
\text { Yahya bin } \\
\text { Ma'in: } \\
\text { Tsiqah; } \\
\text { Ibnu } \\
\text { Hibban: } \\
\text { Termasuk } \\
\text { dari para } \\
\text { huffad } \\
\text { mutqin; } \\
\text { Ibnu Hajar } \\
\text { al- } \\
\text { 'Atsqalani; } \\
\text { Tsiqah } \\
\text { Hafidz } \\
\text { Faqih; Ibnu } \\
\text { Hajar al- } \\
\text { 'Atsqalani: } \\
\text { Abid; Ibnu } \\
\text { Hajar al- } \\
\text { 'Atsqalani: } \\
\text { Imam; } \\
\text { Ibnu Hajar }\end{array}$ & $\begin{array}{l}\text { Tabi'ut } \\
\text { Tabi'in } \\
\text { kalangan } \\
\text { tua }\end{array}$ \\
\hline
\end{tabular}


Jurnal Riset Agama, Volume 1, Nomor 2 (Agustus 2021): 375-388

Hilma Noor Salwa Zakiyyah/Susu Sapi sebagai Obat bagi Kesehatan Tubuh:

Studi Takhrij dan Syarah Hadits

\begin{tabular}{|c|c|c|c|c|c|c|c|}
\hline & & & & & & $\begin{array}{l}\text { al- } \\
\text { 'Atsqalani: } \\
\text { Hujjah; } \\
\text { Adz- } \\
\text { Dzahabi: } \\
\text { Imam }\end{array}$ & \\
\hline 5 & $\begin{array}{l}\text { Abdur } \\
\text { Rahman bin } \\
\text { Mahdy bin } \\
\text { Hassan bin } \\
\text { 'Abdur }\end{array}$ & & $\begin{array}{c}198 \\
\mathrm{H}\end{array}$ & $\begin{array}{l}\text { Bashra } \\
\text { h }\end{array}$ & Abu Sa'id & $\begin{array}{l}\text { Ibnu } \\
\text { Hibban: } \\
\text { Disebutkan } \\
\text { dalam 'ats } \\
\text { tsiqaat; } \\
\text { Ahmad bin } \\
\text { Hambal: } \\
\text { Hafizh; } \\
\text { Ibnul } \\
\text { Madini: } \\
\text { Alamun } \\
\text { Naas; Ibnu } \\
\text { Sa'ad: } \\
\text { Tsiqah; } \\
\text { Abu } \\
\text { Hatim: } \\
\text { Tsiqah } \\
\text { Imam; } \\
\text { Ibnu Hajar } \\
\text { al- } \\
\text { Atsqalani: } \\
\text { Tsiqah } \\
\text { tsabit } \\
\text { hafizh }\end{array}$ & $\begin{array}{l}\text { Tabi'ut } \\
\text { Tabi'in } \\
\text { kalangan } \\
\text { biasa }\end{array}$ \\
\hline 6 & $\begin{array}{l}\text { Ahmad bin } \\
\text { Muhammad } \\
\text { bin Hanbal }\end{array}$ & $\begin{array}{c}164 \\
\mathrm{H}\end{array}$ & $\begin{array}{c}241 \\
\mathrm{H}\end{array}$ & Bagdad & & $\begin{array}{l}\text { Imam } \\
\text { Hadis }\end{array}$ & Mudawin \\
\hline
\end{tabular}

Tabel 1 merupakan daftar rawi dan sanad hadis riwayat Imam Ahmad No. 18077 Kitab Musnad Penduduk Kufah Bab Hadits Thariq bin Syihab radhiallahuta'ala'anhu. Pada tabel tersebut terdapat matrik rawisanad, tahun lahir dan wafat, negeri, kuniyah (panggilan), komentar ulama, dan disebutkan pula kalangannya. Hadis ini diriwayatkan oleh 6 (Enam) orang rawi mulai dari mukharrij sampai mudawwin. Tidak ada rawi yang diketahui tahun lahirnya. Rawi pertama hadis ini ialah Thariq bin Syihab bin 'Abdu Syams bin Hilal bin Salamah bin 'Auf. Sedangkan sanad pertama dari hadis ini ialah Ahmad bin Muhammad bin Hanbal. Berdasarkan Ilmu Hadis, rawi pertama merupakan sanad terakhir 
Jurnal Riset Agama, Volume 1, Nomor 2 (Agustus 2021): 375-388

Hilma Noor Salwa Zakiyyah/Susu Sapi sebagai Obat bagi Kesehatan Tubuh:

Studi Takhrij dan Syarah Hadits

sedangkan rawi terakhir merupakan sanad pertama (Darmalaksana 2020d; Soetari 2015).

\section{Kualitas Hadits tentang Susu Sapi}

Disebut hadits sahih jika rawinya adil dan kuat hafalannya (dhabit), matan hadis tidak janggal (syadz), sanadnya harus bersambung (muttasil), dan matan hadisnya tidak cacat (Darmalaksana 2018). Di tabel 1 telah jelas banyak para ulama yang memberi komentar positif terhadap para rawi dengan memberi komentar tsiqah. Tsiqah merupakan gabungan dari dhabit dan adil (Nadhiran, 2014). Selain itu, komentar ulama sangat bermacammacam cakupannya ada penilaian positif ( $\left.t a^{\prime} d i l\right)$ dan ada juga penilaian negatif (jarh) (Basid 2016; Darmalaksana 2020d; Darmalaksana and Busro 2021; Soetari 2015). Rawi yang dinilai tsiqah berarti ia termasuk orang yang adil dan kuat hapalannya. Selain tsiqah para ulama juga memberikan komentar ahli fiqih tabi'in, disebutkan dalam 'ats tsiqaat, tsabat, laisa bihi $b a^{\prime} s$ dan $l a b a$ 'sa bih. Tetapi pada tabel 1 terdapat komentar yang negatif yaitu pada rawi ke-2 ada yang menyebutkan tertuduh seorang Murjiah. Dengan ini bisa disimpulkan bahwa rawi dalam jalur sanad ini tidak seluruhnya adil dan kuat hafalannya sehingga dapat mempengaruhi kualitas hadis. Namun demikian, meskipun periwayat dinilai negatif karena tertuduh beraliran tertentu, sejauh matan hadis tersebut tidak berkenaan dengan masalah aqidah, maka periwayatan hadis tersebut tetap dapat diterima (Alis 2017). Kemudian syarat sanad bersambung ialah liqa' (bertemu) antara guru (yang menyampaikan hadis) dan murid (yang menerima hadis) dan juga di antara guru dan murid dapat dikatakan bertemu jika mereka sezaman atau mereka berada di satu wilayah (Darmalaksana 2018, 2020d).

Guru dan murid sezaman bisa dilihat dari tahun lahir dan wafat dan mereka berada di satu wilayah bisa diketahui dari negeri para periwayat (Darmalaksana 2018, 2020d). Jika para periwayat tidak diketahui tahun lahir dan wafat, maka para periwayat dapat diasumsikan rata-rata berusia kurang lebih 90 tahun (Darmalaksana 2018, 2020d). Sekalipun pada Tabel 1 beberapa periwayat tidak diketahui tahun lahir dan wafat, namun dengan dugaan tersebut maka para periwayat pada Tabel 1 ditaksir bertemu antara guru dan murid. Dengan kata lain, sanad hadis pada Tabel 1 dapat disebut bersambung. Kualitas hadis bisa naik tingkatannya melalui i'tibar yaitu adanya syahid dan muttabi (Darmalaksana 2018, 2020d; Mardiana and Darmalaksana 2020). Bersumber pada pencarian melalui aplikasi Ensiklopedi Hadits Kitab 9 Imam (Saltanera 2015), hadis riwayat Imam Ahmad No. 18077 Kitab Musnad Penduduk Kufah Bab Hadits Thariq bin Syihab radhiallahuta'ala'anhu tidak tampak diriwayatkan oleh imam lain. 
Jurnal Riset Agama, Volume 1, Nomor 2 (Agustus 2021): 375-388

Hilma Noor Salwa Zakiyyah/Susu Sapi sebagai Obat bagi Kesehatan Tubuh:

Studi Takhrij dan Syarah Hadits

Demikian halnya, status hadis riwayat Imam Ahmad No. 18077 pada dasarnya berkualitas dhaif dalam kata lain tidak memenuhi syarat hadis kualitas sahih. Dan Syu'aib berpendapat bahwa hadits tersebut naik derajatnya menjadi hasan li ghairihi karena hadits tersebut tidak bertentangan dengan aqidah. Sehingga walaupun semula kualitas hadis dinilai dhaif, kualitas hadis riwayat Imam Ahmad No. 18077 naik derajatnya menjadi status hasan li ghairihi. Selain pada sisi rawi dan sanad, hadis sahih menyaratkan matan hadis tidak boleh janggal dan matan hadis tidak boleh cacat (Darmalaksana 2018, 2020d). Dari segi matan, teks hadis tentang susu sapi sebagai obat bagi kesehatan tubuh ini tidak janggal maksudnya struktur kalimat tersusun sistematis dan logis. Dengan demikian, hadis tentang susu sapi sebagai obat bagi kesehatan tubuh bisa diterima sampai bisa diamalkan sekalipun status hadis tidak sampai derajat kualitas sahih.

\section{Syarah Hadis Susu Sapi sebagai Obat bagi Kesehatan Tubuh}

Syarah ialah penjelasan tentang hadis, dan juga syarah yang berhubungan dengan hadis termasuk usaha menjelaskan makna yang ada di dalam teks hadis (Darmalaksana 2020c). Hadis yang bisa diamalkan ( $\left.m a^{\prime} m u l\right)$ berarti hadisnya sudah diterima (maqbul) melalui takhrij (Darmalaksana 2018, 2020d). Bersandarkan takhrij ditemukan bahwa status hadis riwayat Imam Ahmad No. 18077 berkualitas hasan li ghairihi yang mana dari segi sanad bersambung, akan tetapi tidak semua rawi adil dan dhabit pula, akan tetapi dari segi matan tidak ada kejanggalan dan cacat. Hadis riwayat Imam Ahmad No. 18077 memberi keterangan bahwa hadits mengenai susu sapi itu termasuk hadits hasan li ghairihi menurut Syu'aib tetapi bisa diamalkan karena tidak bertentangan dengan aqidah.

Nabi telah menyebutkan bahwa susu adalah minuman yang paling menyehatkan. Oleh karena itu susu memperoleh predikat makanan yang bagus yang dapat menyempurnakan menu. Di dalam susu terkandung semua zat yang diperlukan manusia sejak kecil. Susu sapi merupakan salah satu susu yang memiliki sumber protein hewani yang banyak banyak sekali manfaatnya, dan sebagai bahan pangan yang kaya akan kandungan berbagai zat gizi. Zat gizi yang terdapat dalam susu sapi membuat susu memiliki banyak khasiat bagi tubuh, antara lain untuk pertumbuhan, pemeliharaan, kesehatan, dan kecerdasan (Achroni 2013). Sapi diternakkan untu dikonsumsi daging dan susunya, meski cukup banyak juga yang dimanfaatkan untuk hal lain, seperti menarik kereta, gerobak, dan bajak. Sapi juga banyak disebutkan dalam Al-Qur'an, baik sebagai perumpamaan, petunjuk, maupun sebagai hewan dalam bentuk denotatif. Selain banyak disebutkan dalam Al-Qur'an, sapi juga banyak disebutkan dalam hadits. 
Jurnal Riset Agama, Volume 1, Nomor 2 (Agustus 2021): 375-388

Hilma Noor Salwa Zakiyyah/Susu Sapi sebagai Obat bagi Kesehatan Tubuh:

Studi Takhrij dan Syarah Hadits

\section{Kesimpulan}

Susu sapi merupakan obat bagi kesehatan tubuh karena di dalamnya terkandung semua zat yang diperlukan manusia sejak kecil. Status kualitas hadis tentang susu sapi sebagai obat bagi kesehatan tubuh dinilai hasan li ghairihi berdasarkan takhrij hadis. Dan syarah hadis menunjukkan bahwa susu sapi sebagai obat bagi kesehatan tubuh yang mana di dalam susu sapi terkandung banyak gizi sehingga bermanfaat untuk kesehatan tubuh. Susu sapi merupakan salah satu susu yang memiliki sumber protein hewani yang banyak banyak sekali manfaatnya, dan sebagai bahan pangan yang kaya akan kandungan berbagai zat gizi. Zat gizi yang terdapat dalam susu sapi membuat susu memiliki banyak khasiat bagi tubuh, antara lain untuk pertumbuhan, pemeliharaan, kesehatan, dan kecerdasan di dalamnya terkandung banyak gizi untuk tubuh kita. Oleh karena itu, perbanyak minum susu sapi yang kaya akan manfaat. Diharapkan penelitian ini dapat bermanfaat bagi masyarakat yang ingin mengetahui tentang susu sapi sebagai obat bagi kesehatan tubuh. Diharapkan penelitian ini bisa memberikan manfaat bagi informasi khalayak terutama yang ingin mengetahui takhrij hadis mengenai susu sapi. Dalam penelitian ini mempunyai keterbatasan hanya melakukan takhrij dan syarah hadis tidak melakukan kajian yang mendalam yang berhubungan dengan kesehatan, hingga diperlukan penelitian lebih lanjut dari bidang ilmu kesehatan. Penelitian ini merekomendasikan supaya adanya kolaborasi penelitian lebih lanjut antara peminat ilmu hadis dan ahli kesehatan untuk meneliti yang berhubung dengan manfaat susu sapi dan kesehatan tubuh dari aspek medis.

\section{Daftar Pustaka}

Achroni, Dawud. 2013. Kiat Sukses Usaha Ternak Sapi Perah Skala Kecil. Jogyakarta: Trans Idea Publishing.

Alis, Mohd Kamaro B. I. N. 2017. "Perawi Yang Tertuduh Sebagai Syiah Dalam Shahih Al-Bukhari."

Basid, Abdul. 2016. "Takhrîj Al-H $\square$ adîth Dalam Perspektif Kajian Ontologi Dan Aksiologi Ilmu Hadis." Tafáqquh: Jurnal Penelitian Dan Kajian Keislaman 4(1):78-91.

Christi, Raden Febrianto; Edianingsih, Primiani; Alhuur, Ken Ratu Gharizah. 2019. "Pentingnya Minum Susu Untuk Anak Usia Dini, Remaja Dan Lanjut Usia Di Pesisir Pangandaran." Media Kontak Tani Ternak: Jurnal Pengabdian Kepada Masyarakat 1(2).

Darmalaksana, Wahyudin. 2018. "Paradigma Pemikiran Hadis." Jurnal Aqidah Dan Filsafat Islam 2(1):95-106.

Darmalaksana, Wahyudin. 2020a. "Formula Penelitian Pengalaman Kelas Menulis." Jurnal Kelas Menulis UIN Sunan Gunung Djati Bandung.

Darmalaksana, Wahyudin. 2020b. "Metode Penelitian Kualitatif Studi 
Jurnal Riset Agama, Volume 1, Nomor 2 (Agustus 2021): 375-388

Hilma Noor Salwa Zakiyyah/Susu Sapi sebagai Obat bagi Kesehatan Tubuh:

Studi Takhrij dan Syarah Hadits

Pustaka Dan Studi Lapangan." Pre-Print Digital Library UIN Sunan Gunung Djati Bandung.

Darmalaksana, Wahyudin. 2020c. "Penelitian Metode Syarah Hadis Pendekatan Kontemporer: Sebuah Panduan Skripsi, Tesis, Dan Disertasi." Diroyah: Jurnal Studi Ilmu Hadis 5.

Darmalaksana, Wahyudin. 2020d. "Prosiding Proses Bisnis Validitas Hadis Untuk Perancangan Aplikasi Metode Tahrij." Jurnal Ushuluddin UIN Sunan Gunung Djati Bandung 1:1-7.

Darmalaksana, Wahyudin. 2020e. "Studi Penggunaan Analisis Pendekatan Ilmu-Ilmu Sosial Dalam Penelitian Hadis Metode Syarah." Khazanah Sosial 2(3):155-66.

Darmalaksana, Wahyudin, and Busro Busro. 2021. "Pariwisata Halal Perspektif Ekonomi Syariah: Studi Takhrij Hadis." Masyarakat Pariwisata: Journal of Community Services in Tourism 2(2):99-108.

Darmalaksana, Wahyudin, Lamlam Pahala, and Endang Soetari. 2017. "Kontroversi Hadis Sebagai Sumber Hukum Islam." Wawasan: Jurnal Ilmiah Agama Dan Sosial Budaya 2(2):245-58.

Hadiwiyoto, Suwedo. 1994. "Teori Dan Prosedur Pengujian Mutu Susu Dan Hasil Olahannya." Universitas Sintuwu Maroto Sulawesi Tengah.

Machrus, Ahmad Fida. 2017. "Susu Hewan Ternak Dalam Al-Qur'an (Kajian Tematik)." UIN Walisongo Semarang.

Mardiana, Dede, and Wahyudin Darmalaksana. 2020. “Relevansi Syahid Ma'nawi Dengan Peristiwa Pandemic Covid-19: Studi Matan Pendekatan Ma'anil Hadis." Jurnal Perspektif 4(1):12-19.

Masrur, Ali. 2012. "Diskursus Metodologi Studi Hadis Kontemporer Analisa Komparatif Antara Pendekatan Tradisional Dan Pendekatan Revisionis." Journal of Qur'an and Hadith Studies 1(2):237-49.

Nasrulloh, Nasrulloh. 2020. "Isu Isu Kontemporer Dalam Diskursus AlQur'an Dan Hadis."

Saltanera. 2015. “Ensiklopedi Hadits Kitab 9 Imam." Lembaga Ilmu Dan Dakwah Publikasi Sarana Keagamaan, Lidwa Pusaka. Retrieved (https://store.lidwa.com/get/).

Soetari, Endang. 2015. Syarah Dan Kritik Hadis Dengan Metode Tahrij: Teori Dan Aplikasi. 2nd ed. Bandung: Yayasan Amal Bakti Gombong Layang.

Taufik, Egi Tanadi. 2020. “Syarah Hadis Di Perguruan Tinggi: Genealogis Transmisi Dan Transformasi Metode Syarah Hadis Di Indonesia." Ushuluna: Jurnal Ilmu Ushuluddin 6(2):33-50.

Wardyaningrum, Damayanti. 2011. “Tingkat Kognisi Tentang Konsumsi Susu Pada Ibu Peternak Sapi Perah Lembang Jawa Barat." Jurnal AlAzhar Indonesia Seri Pranata Sosial 1(1):19-26. 
Jurnal Riset Agama, Volume 1, Nomor 2 (Agustus 2021): 375-388

Hilma Noor Salwa Zakiyyah/Susu Sapi sebagai Obat bagi Kesehatan Tubuh: Studi Takhrij dan Syarah Hadits 